\title{
CHARACTERS AND DIALOGUE CONVENTIONS
}

CAITRÍONA PHÁIDÍn Caitríona (daughter of) Páidín. Newly buried PÁDRAig CHAItríona Pádraig (son of) Caitríona. Her only son NóRA SheÁINíN’s DAUGHTER Pádraig Chaitríona’s wife. Living in same house as Caitríona

MÁIrín Girl-child of Pádraig Chaitríona and Nóra Sheáinín’s daughter

NÓRA SHEÁinín Nóra (daughter of) Seáinín. Mother of Pádraig Chaitríona's wife BABA PHÁIDín Baba (daughter of) Páidín. Sister of Caitríona and Nell. Living in America. A legacy from her expected NELL PHÁIDÍN Sister of Caitríona and Baba JACK THE SCOLÓG Jack (son of) Scológ. Nell's husband PEADAR NELL Peadar (son of) Nell and Jack BIG BRIAN's MAG Daughter of Big Brian. Wife of Peadar Nell BRIAN ÓG Young Brian. Son of Peadar Nell and Big Brian’s Mag BIG BRIAN Father of Mag TOMÁS INSIDE Relative of Caitríona and Nell. The two of them contending for his land muraed Phroinsiais Muraed (daughter of) Proinsias. Next-door neighbour and life-long bosom friend to Caitríona Other Neighbours and Acquaintances

\section{Guide to Dialogue Conventions}

- Speech beginning

-... Speech in progress

... Speech omitted 
This page intentionally left blank 